\title{
ASSESSMENT OF SEASONAL PHYSICO-CHEMICAL PARAMETERS OF OGUTA LAKE, NIGERIA.
}

\author{
C.I.A Nwoko ${ }^{1}$, L.N. Ukiwe ${ }^{1}$, U.U. Egereonu ${ }^{1}$, S.N. Ukachukwu ${ }^{1}$ \\ ${ }^{1}$ Department of Chemistry, Federal University of Technology, PMB 1526, Owerri, Nigeria \\ Corresponding author: nwokochristopher@yahoo.com
}

\begin{abstract}
Seasonal variation of physico-chemical variables of Oguta Lake, Nigeria was studied. Results obtained using standard analytical methods indicated that in the rainy and dry seasons (July and August) and (October and November), 2014, iron (Fe; $1.401 \mathrm{mg} / \mathrm{l}$ in November) was the overall metal observed in the lake, while mercury $(\mathrm{Hg})$ was not detected throughout the period of study. Heavy metals concentrations observed were higher (not significantly) during the dry than the rainy season. The values observed for dissolved oxygen (DO), biological and chemical oxygen demand (BOD and COD) were within WHO permissible limits. The above evidence revealed that there was signs of heavy metal $(\mathrm{Fe})$ pollution of the lake, and steps must be taken for constant monitoring of anthropogenic inputs into the lake.
\end{abstract}

\section{Indexing terms/Keywords}

Analytical; characteristics; discharge; domestic; ecosystem; industrial; quality; runoff.

\section{Academic Discipline And Sub-Disciplines}

Environmental chemistry

\section{SUBJECT CLASSIFICATION}

Chemistry

TYPE (METHOD/APPROACH)

Experimental

\section{Council for Innovative Research}

Peer Review Research Publishing System

\section{Journal: Journal of Advances in Chemistry}

Vol 11, No. 7

editorjaconline@gmail.com, www.cirjac.com 


\subsection{INTRODUCTION}

Lakes and rivers are abundant natural resourses of water. Water is necessary to sustain the system. Both urban and rural populations depend on lakes and rivers for their sources of water. However, the quality of these water bodies is not guaranteed due to contamination by heavy metals (HMs).

Heavy metals pollution of lakes and river environments have been researched extensively by scientist all over the world. Heavy metals are mostly toxic, resistant to decomposition, and have the ability to bioaccumulate and affect the ecosystem adversely. Hence, there is need to always monitor environment systems where these metals are present.

Water pollution by HMs occur from effluents of daily domestic and industrial activities which could considerably alter the physical and chemical quality of the water body. Goher et al. (1) noted that water quality monitoring indexing is one of the ways by which the quality of a water system could be assessed. It is important to regularly monitor the water body since this action helps to reveal how healthy and hygienic the water is for use for domestic, industrial and agricultural purposes (2).

Water quality refers to the physico-chemical and biological characteristics of water. Water quality also represents a measure of the condition of the water system relative to end use (3). The quality of water is the most important factor affecting live in the ecosystem. Lakes and rivers being important fresh water sources are polluted by natural and anthropogenic sources (4). Heavy metals are present in these natural and anthropogenic sources, and estimation of the HMs in these systems is essential to ease the burden of pollution (5).

Several authors have documented concerns and main threats posed by HMs in the ecosystem, especially with respect to lakes and rivers in Nigeria. In one study, Salawu et al. (6) investigated seasonal variation of selected HMs in river Maru, Nigeria, and observed that compared to other HMs, zinc $(\mathrm{Zn} ; 1.136 \mathrm{mg} / \mathrm{l})$ was the most HMs contaminant observed in the river. The study also noted that the levels of cadmium $(\mathrm{Cd})$ and lead $(\mathrm{Pb})$ exceeded standard permissible limits. The high levels of $\mathrm{Cd}$ and $\mathrm{Pb}$ in the river was attributed to industrial and agricultural discharge into the river through the use of fertilizers. However, Nsofor et al. (7) had earlier in their study revealed that HMs could alter the histopathology of aquatic species in the rivers. The researchers demonstrated that the high levels of $\mathrm{Pb}$ in the Niger river, Nigeria was linked to dust emanating from combustion of petrol in automobile cars. The dust is washed off into the river as runoff during heavy precipitation.

A recent study to assess the water quality of Oguta lake, Nigeria, revealed that the levels of turbidity, nitrate, iron (Fe), nickel $(\mathrm{Ni})$ and $\mathrm{Cd}$ slightly exceeded maximum permissible limits (8). However, the study concluded that given the levels of nutrients detected in the lake, the problem of pollution of the lake was not severe, and the lake was healthy to sustain aquatic life, since the values observed for other variables such as dissolved oxygen, biological and chemical oxygen demand were within standard permissible limits.

Studies have shown that elevated levels of HMs in lakes and rivers in Nigeria have carcinogenic effects (9),(10); consequently, such water courses should not be used for domestic, industrial and agricultural purposes. Further studies have revealed the presence of large concentration of Fe over other $\mathrm{HMs}$ such as chromium ( $\mathrm{Cr}$ ), $\mathrm{Pb}$ and $\mathrm{Ni}$ in a river. Nontheless, these studies also demonstrated that the concentrations of these HMs in the water body was significantly lower than that in fish tissues habitating in the river (11).

Source protection has been proposed as a way of maintaining the quality of water systems to benefit the ecosystem (12). Reporting on investigations on point and non-point source pollution of Oramiriukwa, Nworie and Otamiri rivers Nigeria, Egereonu et al. (13) noted that source point protection methods such as sewage treatment prevention and industrial effluent off-load monitoring of lakes and rivers are effective approaches that has been applied to manage water quality. In a related study, Obunwo et al. (14) observed that much of the estimated 200,000 tonnes of municipal wastes generated annually in Port Harcourt City, Nigeria is discharged into the city's water courses. This wastes discharge, the authors allege, is responsible for HMs pollution of the Minichida river. Hence, the researchers recommended proper monitoring of discharge of municipal wastes effluents into rivers as a source protection measure. Further studies on physico-chemical variations and HMs pollution of lakes and rivers in Nigeria have been reported by (15),(16),(17) and (18).

In other regions of the world, scientific findings tend to support the generally held belief that the major limitation to usage of water from lakes and rivers is the presence of HMs in these water bodies. In Egypt, it has emerged that the Nile River which has been one of the traditional water sources for the country's economic development is being contaminated by uncontrolled wastewater discharge from the Ismaila Canal (1). Studies on pollution index to assess the levels of contamination of the canal's water revealed the presence of high concentrations of aluminium (Al), manganese $(\mathrm{Mn})$ and Fe. The study further observed that these elements were introduced into the canal by activities of industrial water treatment plants located upstream of the canal (1). In their contributions, the following authors (19),(20) and (21) collaborated the study of (1).

According to Skordas et al. (22), high nutrients and HMs concentrations in Lake Karla, Greece was a manifestation of high loadings of local parent rock materials with anthropogenic origin. Ni and Cr were estimated as potential pollutants of the lake, and compared to labile metal fractions, these to trace metals were less bioavailable. The authors concluded that potential risk arising from high concentrations of HMs in lakes does not solely depend on the overall metal concentrations, but also on bioavailable fractions. The findings by these researchers has been used as baseline evidence for successful management of lakes and rivers, reinterating the early recommendations for close monitoring and control of nutrient loads into water systems to ensure their sustained quality. 
It is important to undertstand the probable source of pollutants of water courses since these water systems have been shown to be residential areas of many unique life forms (23). In some rivers in Tunceli, Turkey, copper (Cu) was distinguished as the highest metal contaminant of the rivers. Copper contamination was observed to be highest during the spring and summer seasons, and human activities such as mining and settlements were implicated for introducing such high concentrations of $\mathrm{Cu}$ in the rivers.

The coast of Bengal also host many lakes and rivers, including the Karnaphuli River. This river has been reported to be heavily polluted in areas close to the Chittagong port channel by discharges of oil and chemical wastes leaking from ships, as well as anthropogenic inputs of phosphate fertilizers into the estuarine zone of the river (24). It was evident from published data that considerable concentrations of $\mathrm{Zn}, \mathrm{Pb}, \mathrm{Cu}, \mathrm{Fe}$ and magnesium (Mg) were present in sediment found in the river and the levels of these metals were relatively higher than standard permissible limits. The investigators recommended proper industrial planning, safe disposal of ship oil and adequate industrial and urban waste management as source protection approaches that when applied could turn the tide against high levels of HMs poisoning of coastal aquatic ecosystem.

Aquatic ecosystems in eastern China have been reported to be in danger of HMs pollution due to rapid economic development and urbanization (25). A recent effort by Tang et al. (25) observed that in five different aquatic ecosystems (river, reservoir, estuary, lake, wetland) studied, higher $\mathrm{HMs}(\mathrm{Cd}, \mathrm{Cr}, \mathrm{Cu}, \mathrm{Ni}, \mathrm{Pb}, \mathrm{Zn}$ ) concentrations were mainly found in sediments samples from river ecosystem. Cadmium was shown to be the most anthropogenically enriched pollutant followed by $\mathrm{Zn}$ and $\mathrm{Pb}$, and the metal $(\mathrm{Cd})$ was also noted as the most serious pollutant in all five ecosystems. It was hoped, the authors cautiously noted, that if concern of Cd contamination is fundamental in developing management strategies for protecting aquatic environments, better procedures for controlling and managing the pollutant could be achieved. Recent advances in HMs contamination of lakes and rivers around the world have been published in several recognized studies including (26).(27) and (28).

The aim of the present study was to examined seasonal variations of physico-chemical variables of Oguta Lake, Nigeria.

\subsection{Materials and Method}

\subsection{Description of study area}

The fishes were bought from commercial fishermen at the daily market in Oguta, Nigeria. Oguta is a town on the East bank of Oguta lake in Imo State, Nigeria; and its geographical coordinates are latitude $5^{\circ} 42^{\prime}$ O" North and longitude $6^{\circ} 48^{\prime} \mathrm{O}^{\prime \prime}$ East, (Fig. 1).

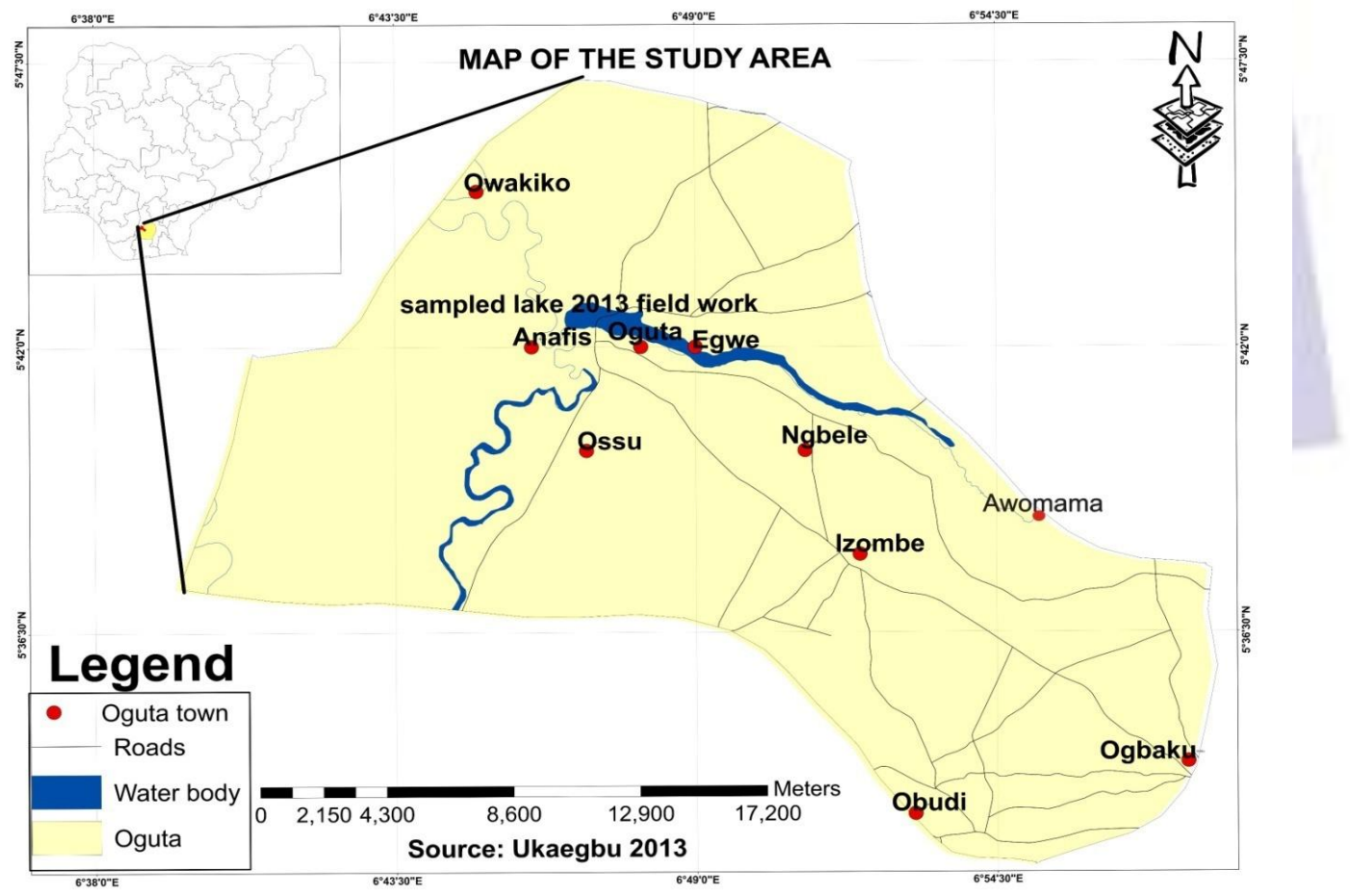

Fig. 1: Map of Oguta lake showing sampling stations (Adopted from Umunnakwe Johnbosco E, and Aharanwa Bibian C (8)) 


\subsection{Water sample collection, preparation and analyses}

Composite sampling method was applied to obtain water samples. Three water samples each collected $1 \mathrm{~km}$ apart from each other in the sampling site were stored in $750 \mathrm{ml}$ plastic bottle previously soaked in $10 \% \mathrm{HNO}_{3}$ for two days and thoroughly rinsed with deionised water. A few drops (about $2 \mathrm{ml}$ conc. $\mathrm{HNO}_{3}$ ) were added to the plastic bottle, the bottle sealed and refrigerated until sample was required for analysis. This procedure stabilizes the sample, maintain the oxidation state of the element, and prevent adhering of the metals to the walls of the container (29). $\mathrm{pH}$, dissolved oxygen and temperature of the water sample were determined at sampling site using a pH meter (Model PHS 25), dissolved oxygen analyzer (Model Jonway 970) and a mercury bulb thermometer, with calibration of $0-360^{\circ} \mathrm{C}$. Other physico-chemical parameters that were later determined in the laboratory include; alkalinity and total hardness by titrimetry. Total dissolved solid, Biological oxygen demand (BOD), chemical oxygen demand (COD), were all determined by method as described by Franson (30). Turbidity was measured using a turbidity meter (WGZ-IB Shanghai), while conductivity was also determined using a conductivity meter (DDS-IIA, Shjinmai). All the chemicals used in the analyses were of analytical reagent grade purchased from BDH Laboratory, Poole, England. Deionised water was obtained from a deionzer (Pure-Aqua Inc, Santa-Ana, CA, USA). For HMs metals (Fe, $\mathrm{Cu}, \mathrm{Pb}, \mathrm{Ni}, \mathrm{Hg}, \mathrm{Cr}, \mathrm{Cd}, \mathrm{As}$ ), analyses was performed as describe by Egereonu et al. (13) using Atomic Absorption Spectrophotometer (AAS) (Model Hitachi FS 240 Varian). Three repetitions were made for each of the physicochemical parameters determined and HMs analyzed. Mean average of three determinants were obtained separately for physicochemical parameter and HMs analysis as described by Ukiwe and Oguzie (31). The above procedure was repeated in August for the rainy season, and then in October and November, respectively, for the dry season.

\subsection{Data analysis}

Data was presented as arithmetic mean and standard deviation. The BMDP Statistical Software was used for data analysis. The one-way Analysis of Variance (ANOVA) was used to determine statistical difference in HMs concentration in water between months. The $F$-test was used to estimate significance in HMs concentration using the above mentioned protocol.

\subsection{Results and Discussion}

\subsection{Results}

Table 1: Mean concentrations of physico-chemical parameters of water sample in the rainy and dry seasons.

\begin{tabular}{|c|c|c|c|c|c|}
\hline $\begin{array}{l}\text { Sampling months } \\
\text { Parameters }\end{array}$ & $\begin{array}{c}\text { July } \\
\text { Mean } \pm \text { SD }\end{array}$ & $\begin{array}{c}\text { August } \\
\text { Mean } \pm \text { SD }\end{array}$ & $\begin{array}{c}\text { October } \\
\text { Mean } \pm \text { SD }\end{array}$ & $\begin{array}{l}\text { November } \\
\text { Mean } \pm \text { SD }\end{array}$ & WHO Standard \\
\hline $\mathrm{Fe}(\mathrm{mg} / \mathrm{l})$ & $0.906 \pm 0.1$ & $0.805 \pm 1.3$ & $1.102 \pm 0.1$ & $1.401 \pm 0.2$ & $<0.50$ \\
\hline $\mathrm{Cu}(\mathrm{mg} / \mathrm{l})$ & $0.071 \pm 0.1$ & $0.101 \pm 1.2$ & $0.975 \pm 0.1$ & $0.865 \pm 0.1$ & $<2.00$ \\
\hline $\mathrm{Pb}(\mathrm{mg} / \mathrm{l})$ & $0.001 \pm 0.0$ & $0.001 \pm 0.0$ & $0.005 \pm 0.0$ & $0.004 \pm 0.0$ & $<0.01$ \\
\hline $\mathrm{Ni}(\mathrm{mg} / \mathrm{l})$ & ND & $0.087 \pm 0.1$ & $0.003 \pm 0.0$ & $0.002 \pm 0.0$ & $<0.02$ \\
\hline $\mathrm{Hg}(\mathrm{mg} / \mathrm{l})$ & ND & ND & ND & ND & $<0.002$ \\
\hline $\mathrm{Cr}(\mathrm{mg} / \mathrm{l})$ & $0.006 \pm 0.0$ & ND & $0.008 \pm 0.1$ & ND & $<0.05$ \\
\hline $\mathrm{Cd}(\mathrm{mg} / \mathrm{l})$ & $0.002 \pm 0.0$ & $0.001 \pm 0.0$ & $0.004 \pm 0.0$ & ND & $<0.003$ \\
\hline As $(\mathrm{mg} / \mathrm{l})$ & $0.001 \pm 0.0$ & ND & $0.001 \pm 0.0$ & ND & $<0.01$ \\
\hline $\mathrm{pH}$ & $6.7 \pm 0.0$ & $6.2 \pm 0.1$ & $6.5 \pm 0.0$ & $6.8 \pm 0.0$ & $6.5-8.5$ \\
\hline Temperature $\left({ }^{\circ} \mathrm{C}\right)$ & $24.6 \pm 0.0$ & $24.2 \pm 0.0$ & $25.7 \pm 0.2$ & $26.2 \pm 0.1$ & $25-28$ \\
\hline Dissolved oxygen (mg/l) & $9.020 \pm 0.1$ & $9.00 \pm 0.1$ & $10.01 \pm 0.1$ & $9.51 \pm 0.1$ & $<6.0$ \\
\hline Alkalinity (mg/l) & $8.721 \pm 1.2$ & $8.011 \pm 1.0$ & $10.46 \pm 0.2$ & $7.716 \pm 0.1$ & $<50$ \\
\hline BOD (mg/l) & $0.172 \pm 1.2$ & $0.252 \pm 0.0$ & $0.216 \pm 0.1$ & $0.328 \pm 0.1$ & $<150$ \\
\hline COD (mg/l) & $0.814 \pm 0.2$ & $0.621 \pm 0.0$ & $0.448 \pm 0.1$ & $0.610 \pm 0.1$ & $<150$ \\
\hline Turbidity (NTU) & $2.161 \pm 0.1$ & $3.140 \pm 0.1$ & $3.612 \pm 0.1$ & $3.470 \pm 0.1$ & $<5.0$ \\
\hline Conductivity $\left(\mu \mathrm{Scm}^{-1}\right)$ & $1.031 \pm 0.1$ & $1.682 \pm 0.1$ & $2.018 \pm 0.1$ & $1.881 \pm 0.1$ & $<250$ \\
\hline Total dissolved solid (mg/l) & $0.482 \pm 1.0$ & $0.614 \pm 0.2$ & $1.116 \pm 0.0$ & $0.574 \pm 0.1$ & $<500$ \\
\hline
\end{tabular}




\subsection{Discussion}

Table 1 shows the mean values of physicochemical parameters of water sample of Oguta Lake in the months of July and August (rainy season) and October and November (dry season). It was observed that Fe $(0.805 \mathrm{mg} / \mathrm{l})$ was the highest HM in the water sample observed in August, while Fe $(0.906 \mathrm{mg} / \mathrm{l})$ was also the highest $\mathrm{HMs}$ observed in the water in July. Nickel and $\mathrm{Hg}$ were not detected in July, while $\mathrm{Hg}$ and $\mathrm{Cr}$ were also not detected in August. For mean physico-chemical values of water sample in October and November, it was observed that 1.102 and $1.401 \mathrm{mg} / \mathrm{l} \mathrm{Fe}$ were present in the water sample in October and November respctively. However, in November, it was also observed that $\mathrm{Hg}, \mathrm{Cr}, \mathrm{Cd}$ and As were not detected in the water, while only $\mathrm{Hg}$ was also not detected in the water sample in October. Copper was the second highest metal detected in the water sample in both months; ( 0.975 and $0.865 \mathrm{mg} / \mathrm{l}$, October and November, respectively). Nickel and Cd were the least detected metals in both months $(0.001 \mathrm{mg} / \mathrm{l} \mathrm{Cd}$, October and $0.002 \mathrm{mg} / \mathrm{l} \mathrm{Ni}$, November).

The elevated level of Fe observed in the present study was not surprising. Studies have suggested that Fe occur at high levels in soil/sediments in aquatic systems in Nigeria (32). Olaifa et al. (33) and Olowu et al. (34) had earlier documented evidence revealing that huge concentrations of HMs are present in water courses in Nigeria. However, in their assessment of water quality and HMs in Oguta Lake, (8) had observed high concentrations of $\mathrm{Fe}$ and $\mathrm{Ni}$ while investigating physico-chemical parameters of the lake in June and September, 2013 and attributed the pollution to dredging activities by oil exploration companies at the bank of the lake. The results of the authors agree with that of the present study with respect to $\mathrm{Fe}$ and $\mathrm{Ni}$ contamination, though the present study reports a slightly low value of Fe and $\mathrm{Ni}$ contamination of the lake in July and October, 2014.

However, the difference in HMs concentrations between seasons (rainy and dry) wasn't significant. The F-test between HMs in July and October was 2.25. Testing this value at 7 and 7 degrees of freedom, $P<0.05$.

\subsection{Conclusion}

The present research has investigated the physico-chemical parameters of water sample from the Oguta Lake, Nigeria, during the rainy and dry seasons of 2014. Mercury was not detected in all the water samples, while As was present in insignificant amount $(0.001 \mathrm{mg} / \mathrm{l})$ in the month of July and October. Iron was the highest HM observed in the water samples in both seasons. The high level of Fe may be attributed to industrial, agrarian and oil exploration activities taking place near the lake. Other HMs and physico-chemical parameters investigated were within WHO maximum permissible limits. Heavy metals were higher (not significantly) during the dry than the rainy season.

\section{References}

1. Goher, M.E., Hassan, A.M., Abdel-Moniem, I.A., Fahny, A.H., El-Sayed, S.M. Evaluation of surface water quality and heavy metal indices of Ismaila Canal, Nile River, Egypt. Egyptian Journal of Aquatic Research, (2014), 40: $225-233$.

2. Poonam, T., Tanushree, B., Sukalyan, C. Water quality indices -important tools for water quality assessment; a review. International Journal of Advance Chemistry, (2013), 1: 15-28.

3. Johnson, D.L., Ambrose, S.H., Winter-Nelson, A.E. Meanings of environmental terms. Journal of Environmental Quality, (1997), 26: 581-587.

4. Tang, A., Liu, R., Ling, M., Wang, J. Distribution characteristics and controlling factors of soluble heavy metals in the Yellow River Estuary and adjacent sea. Procedia Environmental Sciences, (2010), 2: 1193-1198.

5. Zhang, C., Qiao, Q., Piper, J.D.A., Huang, B. Assessment of heavy metal pollution from a Fe-smelting plant in urban river sediments using environmental magnetic and geochemical methods. Environmental Pollution, (2011), 159: 3057-3070.

6. Salawu, K., Owolarafe, T.A., Barau, M.M., Lawal, T.A., Abubakar, M.A., Fadilu, M., Nwachukwu, F.C. Determination of selected heavy metals in seasonal river in Mariu town, Zamfara State, Nigeria. Journal of Environmental and Earth Science, (2014), 4: 11-14.

7. Nsofor, C., Ikpeze, O.O., Ngenegbo, U.C., Ikeogu, C.F., Okonkwo, J.C. Histopathological alterations in the liver and kidney of the fish Chrysichthys nigrodigitatus due to heavy metals in Niger river. Journal of Natural Sciences Research, (2014), 4: 11-18.

8. Umunnakwe, J.E., Aharanwa, B.C. Assessment of water quality and heavy metal levels of fish species in Oguta Lake, Imo State, Nigeria. Journal of Natural Sciences Research, (2014), 4: 103-112.

9. Odoemelam, S.A., Bioacculation of trace elements in fish from Oguta Lake in Nigeria. Journal of Chemical Society of Nigeria, (2005), 30: 18-20.

10. Ishaq, E.S., Rufus, A., Annune, P.A. Bioacculation of heavy metals in fish organs from River Benue, Nigeria. Pakistan Journal of Analytical and Environmental Chemistry, (2011), 129: 25-31.

11. Oboh, I.P., Edema, C.U. Levels of heavy metals in water and fishers from the River Niger. Journal of Chemical Society of Nigeria, (2007), 32: 29-34. 
12. Egboh, S.H.O., Emeshili, E.M. Physico-chemical characteristics of River Ethiope source in Umuaja, Delta State, Nigeria. Journal of Chemical Society of Nigeria, (2007), 32: 72-76.

13. Egereonu, U.U, Ukiwe, L.N., Edet J.A., Ogukwe, C.E. Investigation of pollution index of Oramiriukwa, Nworie and Otamiri Rivers, Imo State, Nigeria. Journal of Chemical Society of Nigeria, (2012), 37: 25-29.

14. Obunwo, C.C., Chinda, A.C., Braide, S.A. Assessment of the physico-chemical characteristics of Minichida stream, Port-Harcourt, Nigeria. Journal of Chemical Society of Nigeria, (2012), 37: 132-136.

15. Ogunfowokan, A.O., Oyekunle, J.A.O., Olutona, G.O., Atoyeli, A.O., Lawal, A. Speciation study of heavy metals in water and sediments from Asunle River of the Obafemi Awolowo University, Ile-Ife, Nigeria. International Journal of Environmental Protection, (2013), 3: 6-16.

16. Jagi, M.O., Bamgbose, O., Odukoya, O.O., Arowolo, T.A. Water quality assessment of Ogun River, Nigeria. Environmental Monitoring and Assessment, (2007), 133: 473-482.

17. Okoye, B.C.O., Afolabi, O.A., Ajao, F.A. Heavy metals in the Lagos lagoon sediments. International Journal of Environmental Studies, (1991), 37: 35-41.

18. Oronsaye, J.A., Nangboye, O.M., Oguzie, F.A. Trace metals in some benthic fishes of the Ikpoba River dam, Benin City, Nigeria. African Journal of Biotechnology, (2010), 9: 8860-8864.

19. Abdo, M.H., El-Nasharty, S.M. Physico-chemical evaluations and trace metals distribution in water-surficial sediment of Ismailia Canal, Egypt. Journal of Natural Science, (2010), 8: 198-206.

20. Geriesh, M.H., Balke, K., El-Bayes, A. Problems of drinking water treatment along Ismailia Canal Province, Egypt. Journal of Zhejiang University Sciences B, (2008), 9: 232-242.

21. Ibrahim, H.S., Ibrahim, M.A., Samhan, F.A. Distribution and bacteria bioavailability of selected metals in sediment of Ismailia Canal, Egypt. Journal of Hazardous Materials, (2009), 168: 1012-1016.

22. Skordas, K., Kelepertzis, E., Kosmidis, D., Panagiotaki, P., Vafidis, D. Assessment of nutrients and heavy metals in the surface sediments of the artificially lake water reservoir Karla, Thessaly, Greece. Environmental Earth Sciences, (2015), 73: 4483-4493.

23. Șeker, S., Kutlu, B. Determination of copper (Cu) levels for rivers in Tunceli, Turkey. World Environmental, (2014), 4: 168-171.

24. Rashid, T., Hoque, S., Akter, S. Pollution in the Bay of Bengal: Impact on marine ecosystem. Open Journal of Marine Science, (2015), 5: 55-63.

25. Tang, W., Shan, B., Zhang, W., Zhang, H., Wang, L., Ding, Y. Heavy metal pollution characteristics of surface sediments in different aquatic ecosystems in eastern China: Acomprehensive understanding. PLos ONE, (2014), 9: e108996.

26. Okbah, M.A., Nasr, S.M., Kasem, S.M. Fractionation of trace metals (Mn, Zn, Cu, Pb) in Red Sea sediments, Gulf of Aden, Yemen. Chemistry and Ecology, (2011), 27: 81-90.

27. Bazzi, A.O. Heavy metals in seawater, sediment and marine organism in the Gulf of Chabahar, Oman Sea. Journal of Oceanography and Marine Science, (2014), 5: 20-29.

28. Wen, C., Kao, C.M., Chen, C.F., Doug, C.D. Distribution and accumulation of heavy metals in sediments of Caohsiung harbor, Taiwan. Chemosphere, (2007), 66: 1431-1440.

29. Ukiwe, L.N., Onyedika, G.O., Uche, V.I., Iwu, C.I. Physico-chemical water quality indicators of groundwater in Ishiagu, Ebonyi State, Nigeria. Terrestrial and Aquatic Environmental Toxicology, (2011), 6: 55-60.

30. Franson, M.A. Standard Methods for the Examination of Water and Wastewater, 14 ${ }^{\text {th }}$ Edn., (1975), APHA-AWAWPCF, New York, USA, pp159-162.

31. Ukiwe, L.N., Oguzie, E. Effect of $\mathrm{pH}$ and acid on heavy metals solubilization of domestic sewage sludge. Terrestrial and Aquatic Enviromental Toxicology, (2008), 2: 54-58.

32. Oyakhilome, G.I., Aiyesanmi, A.F., Adefemi, S.O., Asaolu, S.S. Heavy metals concentration in sediment and fish samples from Owena multi-purpose dam, Ondo State, southern Nigeria. British Journal of Applied Scince and Technology, (2013), 3: 65-76.

33. Olaifa, F.G., Olaifa, A.K., Adelaja, A.A., Owolabi, A.G. Heavy metals contamination of Clarius gariepinus from a lake and fish farm in Ibadan, Nigeria. African Journal of Biomedical Research, (2004), 7: 145-148.

34. Olowu, R.A., Ayejuyo, O.O., Adewuyi, G.O., Adejoro, I.A., Denloye, A.A.A., Babatunde, A.O., Ogundajo, A. Determination of heavy metals in fish tissues, water and sediment from Epe and Badagry lagoons, Lagos, Nigeria. eJournal of Chemistry, (2010), 7: 215-221. 